gonicus, of Aulacomya magellanica, of Patella magellanica, fragments of Otaria jubatu, and a few other mammals, but no human remains, no traces of pottery, no bones split for the extraction of the marrow, no arms or manufactured objects beyond a few rude spear- or arrow-heads. All this offers the most striking analogy to the more recent and modern refuse heaps now being formed, and seems to point at a continuity of population since early quaternary times. The absence of human remains or split bones might even imply that the primitive inhabitants, like their present descendants, were at no period addicted to anthropophagy. In other respects the latter occupy an extremely low social position. They practise no arts beyond the manufacture of frail bark canoes, unchanged since the time of Drake's visit, shell knives, bows, darts, and harpoons. The wigwams are branches stuck in the ground and gathered to a point above, or else a mere guanaco skin (among the Onas) suspended from a tree to windward. Their food is mainly fish, crustaceans, wild berries, mushrooms, cetaceans, greedily devoured in a highly putrescent state. They believe in ghosts and demons, but have no idea of a god, or of any religious worship; are guided rather by instincts than by reason; lack even the matemal sentiment, at least after the period of weaning; show no feeling of real affection for friends or kindred, the only developed sentiment being that of pure selfishness. Their stupidity is such that they are unable to count beyond three, after which everything is vumu-much, many. Yet, in the face of all this the writer was assured by the English missionaries now evangelising these primitive or debased peoples, that the language of the Yahgans, into which they have translated the Cospel of St. Luke, contains no less than 30,000 words, "a wealth contrast ing strangely with their present low state of culture, and naturally suggesting the hypothesis of an origin very different and far superior to the present." But, assuming a former higher state, the difficulty is to understand how such a rich linguistic inheritance could have been preserved for countless generations in their present degraded condition, and amid the adverse surroundings of their present habitat. On this subject clearly more light is demanded.

\section{CHARACTERISTICS OF THE NORTH AMERICAN FLORA ${ }^{1}$}

\section{II.}

THIS contrast is susceptible of explanation. I have ventured to regard the two antipodal floras thus compared as the favoured heirs of the ante-Glacial high northern flora, or rather as the heirs who have retained most of their inheritance. For, inasmuch as the present Arctic flora is essentially the same round the world, and the Tertiary fossil plants entombed in the strata beneath are also largely identical in all the longitudes, we may well infer that the ancestors of the present northern temperate plants were as widely distributed throughout their northern home. In their enforced migration southward, geographical configuration and climatic differences would begin to operate Perhaps the way into Europe was less open than into the lower latitudes of America and Eastern Asia, although there is reason to think that Grcenland was joined to Scandinavia. How cver that be, we know that Europe was fairly well furnished with many of the vegetable types that are now absent, possibly with most of them. Those that have heen recognised are mainly trees and shrubs, which somehow take most readily to fossilisation, but the herbaceous vegetation probably accompanicd the arboreal. At any rate, Europe then possessed Torreyas and Gingkos, Taxodium and Glyptostrobus, Jiboced rus, Pines of our five-leaved type, as well as the analogues of other American forms, several species of Juglans answering to the American forms, and the now peculiarly American genus Carya, Oaks of the American types, Myricas of the two American types, one or two Planer-trees, species of Populus answering to our Cotton-woods and our Balsam-poplar, a Sassafras, and the analogues of our Persea and Benzoin, a Catalpa, Magnolias, and a Liriodendron, Maples answering to ours, and also a Negundo, and such peculiarly American Leguminous genera as the Locust, Honey Locust, and Gymnocladus. To understand how Europe came to lose these elements of her flora, and Atlantic North America to retain them, we must recall the

1 An Address to the Botanists of the British Association for the Advancement of Science; read at Montreal to the Piological Section, August 29, 1834, by Prof. Asa Gray. Continued from p. 235 . poverty of Europe in native forest trees, to which I have already alluded. A few years ago, in an article on this subject, I drew up a sketch of the relative richness of Europe, Atlantic North America, Pacific North America, and the eastern side of temperate Asia in genera and species of forest trees $(A m$. Jonirn. Sci. iii. vi. 85). In that sketch, as I am now convinced, the European forest elements were somewhat under-rated. I allowed only 33 genera and 85 species, while to our Atlantic American forest were assigned 66 genera and I 55 species. I find from Nyman's Conspectus that there are trees on the southern and eastern borders of Europe which I had omitted, that there are good species which I had reckoned as synonyms, and some that may rise to arboreal height which I had counted as shrubs. But on the other hand and for the present purpose it may be rejoined that the list contained several trees, of as many genera, which were probably carried from Asia into Europe by the hand of man. On Nyman's authority I may put into this cateyory Cercis Siliquastrum, Ceratonia Siliqua, Diospyros Lotus, Styrax officinalis, the Olive, and even the Walnut, the Chestnut, and the Cypress. However this may be, it seems clear that the native forest flora of Europe is exceptionally poor, and that it has lost many species and types which once belongec to it. We must suppose that the herbaceous flora has suffered in the same way. I have endeavoured to show how this has naturally come about. I cannot state it more concisely than in the terms which I used six years ago.

"I conceive that three things have conspired to this loss of American, or as we might say, of normal types sustained by Europe. First, Europe, extending but little south of lat, $40^{\circ}$, is all within the limits of severe glacial action. Second, its mountains trend east and west, from the Pyrenees to the Carpathians and the Caucasus beyond; they had glaciers of their own, which must have besun their work and poured down the northward flanks while the plains were still covered with forest on the retreat from the great ice forces coming from the north. Attacked both on front and rear, much of the forest must have perished then and there.

"Third, across the line of retreat of whatever trees may have flanked the mountain ranges, or were stationed south of them, stretched the Mediterranean, an impassable barrier. . . . Escape by the east, and rehabilitation from that quarter until a very late period, was apparently prevented by the piolongation of the Mediterranean to the Caspian, and probably thence to the Siberian Ocean. If we accept the supposition of Norienskjold that, anterior to the Glacial period, Europe was "bounded on the south by an ocean extending from the Atlantic over the present deserts of Sahara and Central Asia to the Pacific,' all chance of these American types having escaped from and re-entered Europe from the south and east seems excluded. Europe may thus be conceived to have been for a time somewhat in the condition in which Greenland is now. . . . Greenland may be referred to as a country which, having undergone extreme glaciation, bears the marks of it in the extreme poverty of its flora, and in the absence of the plants to which its southern portion, extending six degrees below the Arctic circle, might be entitled. It ought to have trees and it might support them. But since their destruction by glaciation no way has been open for their return. Europe fared much better, but has suffered in its degree in a similar way" (American fournal of Sience, l.c., p. I94).

Turning to this country for a contrast, we find the continent on the eastern side unbroken and open from the Arctic circle to the tropic, and the mountains running north and south. The vegetation when pressed on the north by on-coming refrigeration had only to move its southern border southward to enjoy its normal climate over a favourable region of great extent; and, upon the recession of glaciation to the present limit, or in the oscillations which intervened, there was no physical impediment to the adjustment. Then, too, the more southern latitude of this country gave great advantage over Europe. The line of terminal moraines, which marks the limit of glaciation, rarely passes the parallel of $40^{\circ}$ or $39^{\circ}$. Nor have any violent changres occurred here, as they have on the Pacific side of the continent, within the period under question. So, while Europe was suffering hardship, the lines of our Atlantic American flora were cast in pleasant places, and the goodly heritage remains essentially unimpaired.

'The transverse direction and the massiveness of the mountains of Europe, while they have in part determined the comparative poverty of its forest vegetation, have preserved there a rich and widely distributed Alpine flora. That of Atlantic North America 
is insignificant. It consists of a few Arctic plants left scattered upon narrow and scattered mountain-tops, or in cool ravines of moderate elcvation; the maximum altitude is only about 5000 feet in lat. $44^{\circ}$, on the White Mountains of New Hamphire, where no winter snow outlasts midsummer. The best Alpine stations are within easy reach of Montreal. But as almost every species is common to Europe, and the mountains are not magnificent, they offer no great attraction to a European botanist.

Farther south, the Appalachian Mountains are higher, between lat. $36^{\circ}$ and $34^{\circ}$ rising considerahly ahove $6.00 \mathrm{fcct}$; they have botanical attractions of their own, but they have no Alpine plants. A fow sub-Alpine speries linger on the cool shores of Lake Superior at a comparativcly low level. Perhaps as many are found nearly at the levcl of the sea on Anticosti, in the Gulf of St. Lawrence, abnormally cooled by the I abrador current.

The chain of great fresh-water lakes, which are discharged by the brimming St. I awrence, seems to have little effect upon our bolany, beyond the bringing down of a few north-westcrn species. But you may note with interest that they harbour suadry maritime species, mementos of the former saltness of these interior stas. Cakite Americana, much like the European Sea Rocket, Huilsonia tomentosa (a peculiar Cistaceous gonus imitating a Heath), Lathry mariimus, and Ammophila arewaria are the principal. Salicornia, Glaux, Scirpus maritimuts, Ranunulus Cymbularia, and some others may be associated with them. Put these are widely diffused over the saline soil which characterises the plains beyond our wooded resion.

I have thought that some general considerations like these might have more intercst for thei Bological Section at large than any particular indications of our most interesting plants, and of how and where the botanist might find them. Those who in these busy days can find time to herborise will be in the excellent hands of the Candrdian botanists. $\Lambda t$ Philadel phia their brethen of "the States" will be asscmbled to meet their visitors, and the Philadelphians will escort them to their classic ground, the P'ine Barrens of New Jersey. To have an idea of this pecilliar phytogeographical district, you may suppose a long wedge of the Carolina coast to be thrust up nolthward quite to New York harbour, bringing into a comparatively cool climate many of the interesting low country plants of the south, which at this season you would not care to seek in their sultry proper home. Years ago, when Pursh and Leconte and Torrey used to visit it, and in my own younger days, it was wholly primitive and unspoiled. Now, when the shore is lined with huge summer hotels, the Pitcli Pines carried off for firewood, the bogs converted into cranberrysrounds, and much of the light sandy or gravelly soil planter with vineyards or converted into melon and sweet-potato patches, If far it may have lost some of its botanical attractions. But large tracts are still nearly in a state of nature. Drosera filformis, so unlike any uropean species, and the beautiful Sabbatias, the yellow Fringed Orchises, Lachnanthes and Lophiola, the larger Xyrises and Friocations, the curious grass Anphicarpum with cleistogamous flowers at the root, the showy species of Chrysopsis, and many others, must still abound. And every botanist will wish to collect Schizca pusilla, rarest, most local, and among the smallest of ferns.

If only the scason w uld allow it, there is a more southem station of special interest, --Wilmington, on the coast of North Carolina. Cannivorous plants have, of late years, excited the grcatest interest, both popular and scientific, and here, of all places, carnivorous plants seem to have their most varied development. Fur this is the only and the very lucal home of Dionea; here grow almost all the North American spocies of Drosera; here or near hy are most of the species of Sarracenia, of the bladder-bearing Utricularias - one of which the President of our Section has dctected in fish-catching-and also the largest species of Pinguicula.

Put at this season a more cnjoyable excursion may be made to the sonthern portion of the Alleghany or A palachion Mountains, which separate the waters of the Atlantic sitle from those of the Mississipui. These mountains are now easily reached from Philadelphia. In Pennsylvania, where they consist of parallel ridges without peals or crests, and are of no great height, they are less intercsting botanically than in Virginia ; but it is in corth Carolina and the adjacent borders of Tennessee that they rise to their highest altitude, and take on more picturesque forms. On their sides the Atlantic forest, especially its deciduous-lenved portion, is still to be seen to greatest advantage, nearly in pristine condition, and composed of a greater variety of genera and species thar in any other temperate region, excepting Japan. And in their shade are the greatest varicty and abundance of shrubs, and a good share of the most peculiar herbaccous genera. This is the special home of our Rhododendrons, Azalcas, and Kalmias; at least, here they flourish in greatest number and in most luxuriant growth. k'hudodendron maximum (which is found in a scattered way even as far north as the vicinity of Montreal) and K"ilmia latifolia (both called Laurels) even become forest trces in sume places; more commonly they a:e shrubs, forming dense thickets on steep mountain-sides, (hrough which the traveller can make his way only by following old bear-paths, or by keeping strictly on the dividing crests of the leading ridycs.

Only on the summits do we find Rhodotendron Catawbiense, parent of so many handsome forms in English grounds, and on the higher wooded slopes the yellow and the flame-coloured Azalea calenduluea ; on the lower the pink A. nudiflura and more showy $A$. arborescins, along with the common and widesprear $A$, viscosa. The latter part of June is the proper time to explore this region, and, if only one portion can be visited, Roan Mountain should be preferred.

On these mountain-tops we meet with a curious anomaly in geographical distribution. With rarest exccptions, plants which are common to this country and to Europe extend well northward But on these summits from Southern Virginia to Carolina, yet nowhere else, we find-undoubtedly indigenous and undoubtedly identical with the European species-the Lily-of-theValley!

I have given so much of my time to the botany of the Atlantic border that I can barely touch upon that of the western regrions.

Between the wooled country of the Atlantic side of the continent and that of the Pacific side lics a vast extent of plains which are essentially woodless, except where they are traversed by mountain-chains. The prairies of the Atlantic States bordering the Mississippi and of the Winnipeg country shade off into the drier and gradually more saline plains, which, with an even and gradual rise, atrain an elevation of 5000 fcet or more where they abut against the Rocky Monntains. Until these are reached lover a space from the Alleghanies westward of about twenty degrces of longitude) the plains are unbroken. To a moderate distance beyond the Mississippi the country must have been in the main naturally wooded. There is rainfall enough for forest ou these actual prairies. Trees grow fairly well when planted ; they are coming up spontaneously under present opportunities; and there is reason for thinking that all the prairies east of the Mississippi, and of the Missouri up to Minnesota, have been either grcatly extended or were cven made trecless under Indian occupation and annual burnings. These prairies are flowery with a good number of characteristic plants, many of them evilently derived from the plains farther west. At this scason the predominant vegetation is of Compositæ, especially of $\Lambda$ sters and Soliclagoes, and of Sunflowers, Silpliums, and other Helianthoid Compositze

The dijex and barer plains beyond, clothed with the short Buffalo-Grasses, probably never bore trees in their present state, except as now come Cotton-woods (i.e. Pojlars) on the margins of the long rivers which traverse them in their course from the Rocky Mountains to the Mississippi. Westward the plains grow more and more saline; and Wormwoods and Chenopodiacea of various sorts form the dominant vegctation, some of them sui grnis, or at least peculiar to the country, others identical or congeneric with those of the steppes of Northern $\Lambda$ sia. Along with this common campestrine vegetation there is a large infucion of peculiar American types, which I suppose came from the southward, and to which I will again refires.

Then come the Rocky Mountains, traversing the whole continent from no:th to south; their Banks wooded, but not richly so,-chiefiy with Pines and Firs of very fow species, and with a single ubiquitous Poplar, their higher crests bearing a welldeveloped Alpine flora. This is the Arctic hora prolonged southward upon the mountaios of sufficient clevation, with a certain admixture in the lower latitudes of types pertaining to the lower vicinity.

There are almost 200 Alpine Phanogamous species now known on the Rocky Mountains, fully three-quarters of which are Arctic, including Alaskan and Greenlandian; and about half of them arc known in Europe. Several others are North Asian, but not European. Even in that northern portion of 
the Rocky Mountains which the Ass ciation is invited to visit, several Alpine species novel to European botany may be wet with; and farther south the peculiar forms increase. On the other hand, it is interesting to note how many Old World species extend their range southward even to lat. $36^{\circ}$ or $35^{\circ}$.

I have not seen the Rocky Mountains in the Dominion; but I apprehend that the aspect and character of the forest is Canadian, is mainly coniferous, and composed of very few species. Oaks and other cupuliferous trees, which give character to the Atlantic forest, are cntirely wanting, until the southern confines of the region are reached in Colorado and New Mexico, and there they are few and small. In these southern parts there is a lesser amount of forest, but a mucl greater diversity of genera and species, of which the most notable are the Pines of the Mexican platean type.

The Rocky Mountains and the Const Ranges on the Pacific side so nearly approach in British America that their forests merge, and the eastern types are gradually repla:ed by the more peculiar western. But in the United States a broad, arin, and treeless, and even truly desert region is interposed. This has its grcatest breadth and is best known where it is traversed by the Central Pacific Railroad. It is an immense plain between the Rocky Mountains and the Sicrm Nevada, largely a basin with no outlet to the sea, covered with Sage-brush (i.e. peculiar species of Artemisia) and other subsaline vegetation, all of grayish hue ; traversed, mostly north and south, by chains of mountains, which seem to be more bare than the plains, but which hold in their recesses a considemble amount of forest and of other vegetation, mostly of Rocky Mountain types.

Desolate and desert as this region appears, it is far from unin. teresting to the botanist; but I must not stop to show how. Yet cven the ardent botanist feels a sense of relief and exultation when, as he reaches the Sicrra Nevada, he passes abruptly into perhaps the noblest coniferous forest in the world -a forest which stretches along this range and its northern continuation, and along the less elevated ranges which border the Pacific coast, from the southern part of California to Alaska.

So much has been said about this forest, a.bout the two gigantic trees which have made it famous, and its Pines and lits which are hardly less wonderful, and which in Oregon and British Columbia, descending into the plains, yicld far more timber to the acre than can be found anywhere else, and I have myself discoursed upon the subject so largely on former occasions, that I may cut short all discourse upon the Pacific const flora and the questions it brings up.

I note only these points. Although this flora is richer than that of the Atlantic in Conifere (having almost twice as many species), richer incleed than any other except that of Fastern Asia, it is very meagre in deciduons trees. It has a fair number of Oaks, indeed, and it has a Flowering Dogwood, even more showy than that which brightens our eastern woodlands in spring. But altogether it possesses only one-quarter of the number of species of deciduous trees that the Atlantic forest has ; it is even much poorer than Europe in this respect. It is destitute not only of the characteristic trees of the Atlantic side, such as Liriodendron, Magnolia, Asimina, Nyssa, Catalpa, Sassafras, Carya, and the arboreous Leguminosæ (Cercis excepted), but it also wants most of the genera which are common throughout all the other northern temperate floras, having no Lindens, Elms, Mulberries, Celtis, Beech, Chestnut, Hornbeam, and few and small Ashes and Maples. The shrubbery and herbaccous vegetation, although rich and varied, is largely peculiar, especially at the south. At the north we find a fair number of spec cs identical with the castern; but it is interesting to remark that this region, interposed between the NorthEast Asiatic and the North-East $\Lambda$ merican and with coast approximate to the former, has few of those peculiar genera which, as I have insisted, witness to a most remarkable connection between two floras so widely sundered geographically. Some of these types, indced, occur in the intermediate region, rondering the general absence the more noteworthy. And certain peculiar types are represented in single identical species on the coasts of Oregon and Jajan, \&c. (such as Lysichiton, Fatsia, Glehnia); yet there is less community hetween these floras than might be expected from their geographical proximity at the north. Of course the high northern flora is not here in view.

Now if, as I have maintained, the eastern side of North America and the eastern side of Northern Asia are the favoured heirs of the old boreal flora, and if I have plau-ibly explained how Europe lost so much of its portion of a common inheritance, it only remains to consider how the western side of North America lost so much more. For that the missing types once existed there, as well as in Europe, has already been indicated in the few fossil explorations that have been made. They have brought to light Magnolias, EIm:, Beeches, Chestnut, a Liquidambar, \&c. And living witnesses remain in the two Sequoias of California, whose ancestors, along with Taxodium, which is similarly preserved on the Atlantic side, appear to have formed no small part of the Miocene flora of the Arctic regions.

Several causes may have conspired in the destruction;climatic differences between the two sides of the continent, such as must early have been established (and we know that a difference no greater than the present would be effective) ; geographical configuration, probably confining the migration to and fro to a long and narrow tract, little wider, perbaps, than that to which it is now restricted ; the tremendous outpouring of lava and volcanic ashes just anterior to the Glacial period, by which a large part of the region was thickly covered; and, at length, competition from the Mexican plateau vegetation, $\rightarrow$ a vegetation beyond the reach of general glacial movement from the north, and climatically well adapted to the south-western portion of the United States.

It is now becoming obvious that the Mexican plateal vegetation is the proximate source of most of the peculiar elements of the Californian flora, as also of the southern Rocky Mountain region and of the Great Basin betixeen; and that these plants from the south have competed with those from the north on the eastward plains and prairies. It is from this source that are derived not only our Cactex but our Mimosex, our Daleas and Petalostemons, our numerous and varied Onagracea, our Loasacex, a large part of our Compositæ, especially the Eupatoriaceæ, Helianthoideæ, Ielenioideæ, and Mutisiaceæ, which are so characteristic of the country, the $\Lambda$ sclepiader, the very numerous Polemoniacex, IIydrophyllaceæ, Eriogoneæ, and the like.

I had formerly recognised this element in our North American flora, but I have only recently come to apprehend its full significance. With increasing knowledge we may in a good measure discriminate between the descendants of the ancient northern flora and those which come from the highlands of the sonth-west.

\section{BRYN MAWR COLLEGE}

T'IIS College is an Institution for Women, founded by the late Dr. Joseph W. Taylor; the following account of its foundation and objects, from the Philadelphia Ledjer, has been kindly forwarded to us by Prof. Sylvester.

The work on the buildings and other preparations for the opening of the College are being pushed forward as expeditiously as possible, so that everything will be ready by June next. This new educational institution, it will be remembered, was founded by the late Joseph W. Taylor, M.D., a prominent member of the Society of Friends, of Bullington, N.J., who bought the land-about thirty-two acres-and began the erection of the college building; in 1879 . He died in January, I880, leaving an endowment of 800,000 dols. for the continuance of the work he had begun--the erection and starting of a college for women.

By the terms of the will of the founder, the Trustees are members of the Society of Friends, but the students may be of any denomination, and their religious belief is to be respected. It was part of the purpose of Dr. Taylor to give to women of intelligence and refinement the best opportunities for culture, combined with Christian infuences and social amenities. Scholars under sixteen years will be ineligible for admission. The Board of Trustees consists of : President-Francis $\mathrm{T}$. King, of Baltimore, Md. ; Charles S. Taylor, Burlington, N.l. ; James C. Thomas, Baltimore, Md. ; James E. Rhoades, Philadelphia; James Whitall, Philadelphia; John B. Garrett, Bryn Mawr, Penn.; Charles Harteshorne, Philadelphia; David Scull, Jr., Philadelphia; William R. Thurston, New York City; Albert K. Smiley, Lake Mohonk, N.Y.; Francis R. Cope, Philadelphia; Philip C. Carrett, Philadelphia, and Edward Bittle, Philadelphia.

As Dr. Taylor did not wish the college named after him, the Trustees have given the title of Taylor Hall to the main building, in commemoration of his munificcnt bequest. This building, 